Jurnal Ilmu Olahraga Volume I Nomor 1 Oktober 2018

Isti Dwi Puspita Wati

Tersedia di http://jurnal.untan.ac.id/index.php/jilo

\title{
PROSENTASE PEMENUHAN GIZI MAKRO PADA ATLET TARUNG DERAJAT PERSIAPAN PON BANDUNG 2016
}

\author{
Isti Dwi Puspita Wati, staf pengajar di Pendidikan Kepelatihan Olahraga FKIP- UNTAN \\ Email.istidpw@gmail.com
}

\begin{abstract}
Abstrak
Penelitian ini bertujuan untuk mengetahui pemenuhan gizi makro atlet tarung drajat dalam persiapan PON bandung 2016. Sampel terdiri dari 15 atlet 8 putra, 7 putri. Data diperoleh dengan menggunakan angket food frecuency questionare (FFQ). Hasil penelitian menunjukkan bahwa pemenuhan karbohidrat terpenuhi, lemak dan protein berlebih. Berdasarkan hasil tersebut ada kerugian terhadap pengaturan berat badan. Yang kedua energy yang seharusnya dipergunakan untuk aktivitas terjadi pemborosan untuk melakukan metabolism lemak dan protein.
\end{abstract}

Kata kunci: gizi makro, atlet, karbohidra, lemak, protein 


\section{Jurnal Ilmu Olahraga Volume I Nomor 1 Oktober 2018 \\ Isti Dwi Puspita Wati \\ Tersedia di http://jurnal.untan.ac.id/index.php/jilo}

\section{PENDAHULUAN.}

Olahragawan memerlukan pemenuhan gizi yang seimbang untuk terjadinya adaptasi latihan. Keseimbangan antara beban latihan dan pemenuhan gizi sangat menentukan keberhasilan pencapaian kondisi puncak. Kondisi puncak diharapkan terjadi ketika atlet bertanding. Kegagalan pencapaian kondisi puncak akan mengakibatkan penurunan prestasi dalam pertandingan. Dikatakan mengenai diet atau pemenuhan gizi ini adalah bahwa kekurangan khususnya sumber energy akan berakibat pada massa otot yang tidak optimal, terjadi ganguan terhadap proses menstruasi pada atlet putri, pemulihan yang tidak sempurna, terjadi resiko kelelahan yang berlebih serta bahaya cidera yang mengancam, yang paling riskan adalah terganggunya proses pemulihan (Rodriques et al, 2009).

Berkaitan dengan hal tersebut khususnya tarung drajat serta semua cabang yang memerlukan pengaturan berat badan sebagai syarat utama, maka pengaturan asupan makanan sangat penting dan fital. Sebagai ilustrasi bahwa oksidasi karbohidrat membutuhkan waktu 2-4 jam, lemak 6 jam, protein lebih dari 6 jam. Ketika atlet akan bertanding maka pelatih harus menyarankan dan mengkondisikan bahwa ketika jam bertanding secara fisiologis tubuh tidak lagi terbebani dengan pencernaan sesuai dengan perhitungan waktu metabolism dari gizi makro tersebut. Ketika misalnya atlet akan bertanding jam 10.00 pagi, maka setidaknya jam 06.00 atlet tersebut harus sudah selesai makan jika menu yang di konsumsi adalah karbohidrat. Dengan pengertian lain jangan mengambil resiko untuk makan makanan yang berlebak dan berprotein tinggi menjelang pertandingan. Hal in akan berakibat pembebanan pada system pencernaan.
Keterkaitan dengan hal tersebut diatas Irianto (2007) menyatakan bahwa pengaturan makanan terhadap seorang atlet harus individual. Peernyataan ini jelas berimplikasi pada pemenuhan energy yang diperlukan untuk bertanding. Berbeda antara atlet daya tahan dan atlet yang bertanding dengan intensitas tinggi yang hanya sesaat. Kebiasaan pengaturan asupan makanan selama berlatih pastinya akan dibawa atlet sampai pertandingan yang akan dilaksanakan. Hal ini menjadi sangat penting karena kesalahan dalam memberikan asupan makanan akan berakibat fatal pada prestasi.

Pemenuhan nutrisi sangat penting hal ini berdasarkan pada kutipan sebagi berikut faktor nutrisi yang dibutuhkan oleh atlet dalam latihan untuk mendapatkan performa yang bagus adalah : 1) kecukupan energi, 2) waktu yang tepat dalam mengkonsumsi kebutuhan cairan, 3) waktu yang tepat dalam mengkonsumsi karbohidrat dan protein, dan 4) pemilihan yang tepat dalam mengkonsumsi supplement (ASCM, 2009). Hal pertama yang sangat penting adalah kecukupan energi. Sumber energi utama adalah karbohidrat baru kemudian lemak dan protein. Ketiga sumber energy ini dikenal dengan gizi makro. Hal terpenting kedua adalah ketepatan dalam pemberian cairan. Cairan menjadi sangat penting, karena kehilangan $1 \%$ saja dari kandungan air yang ada di tubuh maka akan menurunkan konsentrasi. Konsentrasi sangat berperan penting dalam setiap pertandingan. Sehingga menjaga tingkat hidrasi tubuh merupakan hal yang sangat penting dan akan sangat menyumbang terhadap kinerja yang tinggi. Hal ketiga sangat spesifik adalah kapan penemuhan karbohidrat dan protein. Karbohidrat merupakan sumber energy utama dan yang paling cepat diproses dan hanya memerlukan paling sedikit oksigen ketika 
dioksidasi di mitokondria. Protein adalah zat gizi yang paling lama dicerna dan paling boros oksigen ketika di oksidasi. Protein adalah zat pembangun ketika terjadi kerusakan. Ketika latihan sangat berat yang harus dicukupi pertama kali adalah karbohidat sebagai pengganti energy yang kaluar dan protein sebagai zat pembangun ketika ada kerusakan. Harus tepat dalam memberikan asupan, kelebihan karbohidrat akan disimpan dalam bentuk lebak, kelebihan protein akan dibuang dan akan memberi beban tambahan terhadap percernaan dan oksidasi. Hal keempat yang penting adalah pemilihan suplemen yang tepat. Suplemen biasanya adalah pemenuhan gizi mikro. Untuk atlet lebih cenderung pada suplemen yang merangsang pembentukan sel darah merah dan seng.

Atlet melakukan latihan berdasarkan periodesasi, mulai dari periode persiapan sampai periode kompetisi. Periode persiapan umum ketika kekuatan maksimal diperlukan maka asupan protein dan karbohidrat harus cukup untuk meningkatkan massa otot. Ketika periode mendekati pertandingan maka asupan protein diturunkan agar tidak menjadi beban pencernaan dan system energy. Pengetahuan dasar gizi bagi atlet dan pelatih sangat penting. Hal ini memberikan bekal terhadap pengaturan gizi seimbang sebagai status pelatih dan memberikan saran yang bijak kepada atlet agar terjadi keseimbangan antara program latihan yang dilakukan terhadap fisik serta bagaimana mencukupi agar terjadi adaptasi yang maksimal.

Sangat penting untuk diterapkan pengarutan gizi seimbang bagi atlet. Dikatakan putra da putri berbeda, lain kecabangan juga berbeda. Pada tahun 2016 ini Kalimantan Barat adalah salah satu Provinsi peserta PON di Jawa Barat. Salah satu cabang yang menjadi unggulan adalah tarung drajat. Cabang ini jelas memerlukan pengaturan berat badan yang baik sampai pertandingan karena berat badan menjadi kreteria pembagian kelas. Jika melakuan diet kelebihan energy ketika latihan maka akan berakibat pada kenaikan berat badan, jika kurang maka akan terjadi sebaliknya. Ketika mendekati pertandingan, ketika terjadi kelebihan protein maka akan membebani terhadap pencernaan dan system energy, dan jika berlebih karbohidrat juga akan mengancap terhadap kenaikan berat badan. Berkaitan dengan hal ini peneliti meneliti bagaimana asupan gizi makro (karbohidrat, lemak dan Protein) atlet PON tarung drajat di Kalimantan Barat.

\section{Metode Penelitian}

Penelitian ini merupakan penelitian studi kasus terhadap satu cabang olahraga tarung drajat dalam upaya pemenuhan gizi makro dalam persiapan menghadapi PON Bandung 2016. Sampel adalah 15 atlet 8 putra dan 7 putri. Data diperoleh dengan menggunakan Food frequency questionnaire (FFQ). Setelah data terkumpul dianalisis dengan membandingkan norma kecukupan gizi dengan kenyataan di lapangan dengan persentase.

\section{HASIL DAN PEMBAHASAN}

\section{Hasil Penelitian}

Penelitian dilakukan pada masa training centre (TC) dilakukan pada atlet yang akan diberangkatkan untuk berpartisipasi pada PON 19 di Jawa Barat pada bulan Septermber 2016. TC dilakukan tidak terpusat, akan tetapi dilakukan masingmasing oleh cabang olahraga yang bersangkutan sendiri-sendiri. Adapun komplek latihan yang digunakan adalah diseputaran KONI Pontianak,

Cabang olahraga tarung drajat merupakan salah satu cabang olahraga 
Jurnal Ilmu Olahraga Volume I Nomor 1 Oktober 2018

Isti Dwi Puspita Wati

Tersedia di http://jurnal.untan.ac.id/index.php/jilo

unggulan di Propinsi Kalimantan Barat. Jumlah atlet dari cabang olahraga ini sebanyak 15 atlet masing-masing pembagian pada tabel 1

\section{Tabel 1. Distribusi Frekuensi Atlet} Cabang Olahraga Tarung Derajat

\begin{tabular}{lcc}
\hline No & $\begin{array}{c}\text { Jenis } \\
\text { Kelamin }\end{array}$ & $\begin{array}{c}\text { Jumlah } \\
\text { Atlet }\end{array}$ \\
\hline 1. & Laki-laki & 8 \\
\hline 2. & Perempuan & 7 \\
\hline & Total atlet & 15 \\
\hline
\end{tabular}

Atlet menghabiskan banyak waktu dan upaya dalam menjaga dan memanipulasi keseimbangan energi. Tergantung pada jenis dan karakteristik olahraga, atlet berlatih guna membentuk, menghilangkan dan atau menjaga berat badan. Pemenuhan asupan makan sangat tergantung pada jenis olahraga yang dilakukan. Sehingga pemenuhan asupan makanan sangat individual sesuai dengan karakteristik cabang olahraga dan latihan yang dilakukan. Manipulasi keseimbangan energi merupakan hal yang penting dilakukan untuk atlet bukan hanya berdasarkan berat badan saja akan tetapi berkaitan dnegan proporsi lemak tubuh, cadangan karbohhidrat, status vitamin dan mineral, kesehatan tulang dan status mentruasi pada wanita (Thompson, 1998).

Kecukupan energi merupakan status ketika energi yang masuk seimbang dengan energi yang dikeluarkan. Kegagalan dalam menyamakan energi yang masuk dan energi yang keluar dapat menyebabkan ketidakseimbangan energi. Ketidakseimbangan energi terbagi dalam dua kelompok yaitu kelompok positif dimana energi yang masuk lebih banyak daripada energi yang keluar sehingga muncul berat badan berlebih dan kelompok negative dimana energi yang masuk lebih sedikit daripada energi yang keluar sehingga muncul kekurangan berat badan. Kebutuhan energi tergantung pada tahap perkembangan atlet dan usia. Atlet yang masih dalam usia pertumbuhan memerlukan energi yang lebih dibandingkan dengan atlet yang tidak dalam masa pertumbuhan.

Tabel 2. Standarisasi pemenuhan asupan zat gizi makro

\begin{tabular}{lll}
\hline No & Zat Gizi & $\begin{array}{l}\text { Prosentase } \\
\text { pemenuhan }\end{array}$ \\
\hline 1. & Karbohidrat & $>55 \%$ \\
\hline 2. & Protein & $<30 \%$ \\
\hline 3. & Lemak & $12 \%$ \\
\hline
\end{tabular}

Berdasarkan hasil penelitian pada atlet cabang olahraga tarung derajat yang diberangkatkan pada PON ke 19 di Jawa Barat diperoleh data sebagai berikut :

Tabel 3. Statistika Deskriptif Prosentase pemenuhan asupan gizi makro atlet cabang olahraga tarung derajat

\begin{tabular}{cccc}
\hline & Karbohidrat & Protein & Lemak \\
\hline Mean & 71.87 & 107.13 & 68.67 \\
\hline median & 61.00 & 84.00 & 53.00 \\
\hline modus & 61.00 & 81.00 & 53.00
\end{tabular}

Berdasarkan data di atas maka dapat dillihat bahwa dalam kebutuhan kalori harian para atlet rata-rata mengkonsumsi karbohidrat sebanyak 71,87\%, 107,13 \% dari protein dan $68,67 \%$ dari lemak. Secara rinci asupan karbohidrat dari atlet tarung derajat dapat dilihat dalam tabel 3 sebagai berikut :

Tabel 4. Asupan Karbohidrat Pada Atlet Pon Cabang Olahraga Tarung Derajat Di Propinsi Kalimantan Barat.

\begin{tabular}{llr}
\hline Kategori & Interval & Frekuensi \\
\hline Kurang & $<55$ & 4 \\
\hline Cukup & $56-100$ & 9 \\
\hline Lebih & $>100$ & 2 \\
\hline
\end{tabular}


Karbohidrat merupakan sumber energi utama yang digunakan oleh tubuh untuk dapat beraktivitas. Kebutuhan kalori tubuh seharusnya dipenuhi lebih dari 55\% dari karbohidrat. Dari penelitian yang dilakukan mengungkapkan bahwa terdapat 4 atlet tarung derajat mengalami kekurangan asupan karbohidrat, 9 atlet terpenuhi asupan karbohidrat dan 2 atlet memiliki asupan karbohidrat yang melebihi.

Lemak merupakan sumber energi kedua yang dapat digunakan oleh tubuh untuk beraktivitas. Pemenuhan terhadap lemak juga merupakan hal yang penting dalam mendukung tubuh dapat maksimal beraktivitas. Kebutuhan lemak bagi tubuh tidak lebih dari 30\% dari total kalori tubuh yang diperlukan.

Tabel 5. Asupan Lemak Pada Atlet Pon Cabang Olahraga Unggulan Di Propinsi Kalimantan Barat.

\begin{tabular}{llr}
\hline Kategori & Interval & Frekuensi \\
\hline Kurang & $<15$ & 0 \\
\hline Cukup & $15-30$ & 0 \\
\hline Lebih & $>30$ & 15 \\
\hline
\end{tabular}

Berdasarkan tabel diatas maka dapat dilihat bahwa $100 \%$ atlet tarung derajat mengkonsumsi terlalu banyak makanan yang mengandung lemak. Hal ini dapat dilihat dari pemenuhan kebutuhan lemak bagi tubuh atlet yang anjuran yang tepat mengkonsumsi lemak sebanyak kurang dari $30 \%$.

Protein merupakan sumber energi yang terakhir yang dapat digunakan oleh tubuh untuk dapat beraktivitas. Namun anjuran konsumsi protein dalam kebutuhan harian tubuh cukup $12 \%$ dari total kebutuhan kalori. Berdasarkan penelitian yang dilakukan diperoleh data sebagai berikut:

\section{Tabel 6. Asupan Protein Pada Atlet Pon Cabang Olahraga Tarung Derajat Di Propinsi Kalimantan Barat.}

\begin{tabular}{llr}
\hline Kategori & Interval & Frekuensi \\
\hline Kurang & $<8$ & 0 \\
\hline Cukup & $8-12$ & 0 \\
\hline Lebih & $>12$ & 15 \\
\hline
\end{tabular}

Berdasarkan tabel diatas maka dapat dilihat bahwa $100 \%$ atlet tarung derajat mengkonsumsi terlalu banyak makanan yang mengandung protein. Hal ini dapat dilihat dari pemenuhan kebutuhan lemak bagi tubuh atlet yang anjuran yang tepat mengkonsumsi lemak sebanyak kurang dari $30 \%$.

Tabel 7. Prosentase pemenuhan zat gizi makro atlet tarung derajat

\begin{tabular}{clccc}
\hline No & $\begin{array}{l}\text { Jenis } \\
\text { Kela } \\
\text { min }\end{array}$ & $\begin{array}{c}\text { Pemenuh } \\
\text { an } \\
\text { Karbohid } \\
\text { rat }\end{array}$ & $\begin{array}{c}\text { Pemenuha } \\
\text { n Lemak }\end{array}$ & $\begin{array}{c}\text { Pemenuh } \\
\text { an } \\
\text { Protein }\end{array}$ \\
\hline $\mathbf{1}$ & $\mathrm{L}$ & $62 \%$ & $111 \%$ & $158 \%$ \\
\hline $\mathbf{2}$ & $\mathrm{P}$ & $57 \%$ & $35 \%$ & $55 \%$ \\
\hline $\mathbf{3}$ & $\mathrm{P}$ & $54 \%$ & $31 \%$ & $45 \%$ \\
\hline $\mathbf{4}$ & $\mathrm{P}$ & $65 \%$ & $40 \%$ & $63 \%$ \\
\hline $\mathbf{5}$ & $\mathrm{L}$ & $61 \%$ & $48 \%$ & $81 \%$ \\
\hline $\mathbf{6}$ & $\mathrm{L}$ & $50 \%$ & $47 \%$ & $81 \%$ \\
\hline $\mathbf{7}$ & $\mathrm{L}$ & $183 \%$ & $162 \%$ & $256 \%$ \\
\hline $\mathbf{8}$ & $\mathrm{L}$ & $78 \%$ & $57 \%$ & $99 \%$ \\
\hline $\mathbf{9}$ & $\mathrm{L}$ & $59 \%$ & $56 \%$ & $76 \%$ \\
\hline $\mathbf{1 0}$ & $\mathrm{L}$ & $60 \%$ & $36 \%$ & $58 \%$ \\
\hline $\mathbf{1 1}$ & $\mathrm{P}$ & $117 \%$ & $176 \%$ & $259 \%$ \\
\hline $\mathbf{1 2}$ & $\mathrm{P}$ & $52 \%$ & $53 \%$ & $84 \%$ \\
\hline $\mathbf{1 3}$ & $\mathrm{P}$ & $61 \%$ & $67 \%$ & $109 \%$ \\
\hline $\mathbf{1 4}$ & $\mathrm{P}$ & $55 \%$ & $53 \%$ & $97 \%$ \\
\hline $\mathbf{1 5}$ & $\mathrm{P}$ & $64 \%$ & $58 \%$ & $86 \%$ \\
\hline & & & & \\
\hline
\end{tabular}


Jurnal Ilmu Olahraga Volume I Nomor 1 Oktober 2018

Isti Dwi Puspita Wati

Tersedia di http://jurnal.untan.ac.id/index.php/jilo

Dalam penelitian ini menemukan bahwa meskipun secara rerata atlet tarung derajat mengkonsumsi karbohhidrat cukup, ditinjau dari mean prosentase pemenuhan yang menunjukkan angka $71,87 \%$ namun atlet terdapat atlet yang mengalami kekurangan asupan karbohidrat. Selain itu juga terdapat 2 orang atlet yang mengkonsumsi terlalu banyak karbohidrat bahkan lebih dari $100 \%$ dari kebutuhan kalori harian.

Kekurangan maupun kelebihan karbohidrat akan berdampak negative bagi tubuh atlet. Kekurangan karbohidrat akan mengakibatkan tubuh mengalami penurunan performa. Kekurangan secara berkelanjutan akan berdampak pada penurunan berat badan atlet itu sendiri. Demikian juga sebaliknya, bagi atlet yang mengkonsumsi terlalu banyak maka akan berdampak pada peningkatan berat badan yang tentunya akan mengganggu performa pada saat bertanding nanti bahkan akan berpindah kelas, mengingat cabang olahraga merupakan cabang olahraga yang menggunakan criteria berat badan sebagai pengelompokan kelas.

Lemak dan protein merupakan sumber energi setelah karbohidrat, sehingga kebutuhan harian untuk kedua sumber energi tidak terlalu banyak seperti halnya karbohidrat. Kurang dari $30 \%$ dan $12 \%$ merupakan anjuran mengkonsumsi protein dan lemak. Namun dalam penelitian yang dilakukan, sebanyak 6 atlet yang mengkonsumsi lemak lebih dari 30\% namun kurang dari $50 \%$ dari total kebutuhan energi. Sedangkan 9 atlet yang lain mengkonsumsi lemak lebih dari 50\%. Hal ini dapat membahayakan tubuh atlet. Dimana kelebihan lemak yang dikonsumsi oleh atlet akan menyebabkan organ-organ tubuh tidak dapat bekerja sebagaimana mestinya.

Prosentase pemenuhan protein pada atlet tarung derajat lebih dari 50\% dari kebutuhan total kalori sebanyak 14 atlet.
Angka kecukupan protein yang dianjurkan adalah sebesar $12 \%$ dari kebutuhan total harian atlet. sehingga dapat disimpulkan bahwa $100 \%$ atlet mengalami kelebihan dalam mengkonsumsi protein.

\section{Pembahasan}

Setiap aktivitas memerlukan energi. Energi yang digunakan oleh manusia untuk beraktivitas berasal dari makanan yang dikonsumsi setiap hari.

Angka kecukupan energy bagi para atlet rata-rata sekitar $2500 \mathrm{kcal}$ per hari, namun hanya beberapa dari atlet yang mampu memenuhi kecukupan energy yang dibutuhkan. Atlet memerlukan $58-60 \%$ karbohidrat, $15-16 \%$ protein dan $25-28 \%$ lemak atau lebih spesifik $6-10 \mathrm{~g} / \mathrm{kg}$ berat badan harus dipenuhi oleh karbohidrat, 1,4 $2 \mathrm{~g} / \mathrm{kg}$ berat badan dari protein dan $1,7-2,4$ $\mathrm{g} / \mathrm{kg}$ berat badan dari lemak (ADA, 2000). Jika terjadi kekurangan maka adan memilik dampak. Dampak yang akan timbul dari kekurangan dalam menu diet adalah sebagai berikut tabel 8

Tabel 8 Kekurangan Zat Gizi Dan Dampaknya.

\begin{tabular}{ll}
\hline $\begin{array}{l}\text { Kekurangan } \\
\text { karbohidrat }\end{array}$ & $\begin{array}{l}\text { Ketidakcukupan cadangan } \\
\text { glikogen dan kelelahan }\end{array}$ \\
& awal \\
& Meningkatkan penggunaan \\
& cadangan protein tubuh \\
& sebagai sumber energi
\end{tabular}

Kekurangan Terbatasnya sistesis asam vitamin B6 amino dan produksi sel darah merah

Kekurangan Merusak zat pembawa zat besi oksigen (Haemoglobin/Hb) Dapat menyebabkan anemia

\begin{tabular}{ll}
\hline $\begin{array}{l}\text { Kekurangan } \\
\text { asam folat dan } \\
\text { seng }\end{array}$ & $\begin{array}{l}\text { Menghambat pertumbuhan } \\
\text { dan penggantian sel yang } \\
\text { rusak }\end{array}$ \\
\hline $\begin{array}{l}\text { Kekurangan } \\
\text { kalsium }\end{array}$ & $\begin{array}{l}\text { Mengganggu pembangunan } \\
\text { dan pemadatan massa tulang }\end{array}$ \\
\hline
\end{tabular}


Jurnal Ilmu Olahraga Volume I Nomor 1 Oktober 2018

Isti Dwi Puspita Wati

Tersedia di http://jurnal.untan.ac.id/index.php/jilo

(Sumber : Sherman et al, 1989 dan Whitney and Rolfes, 1996)

Berdasarkan hasil penelitian yang dilakukan terhadap 15 atlet yang sedang dalam proses melaksanakan latihan dapat dipahami terjadi beberapa hal sebagai berikut. Sebagai pengantar berikut dikutip Papadopoulou (2015) juga menemukan bahwa atlet bola voli elit juga mengalami kekurangan asupan energi baik itu dalam zat gizi makro (karbohidrat, Protein dan Lemak) dan zat gizi mikro (vitamin $\mathrm{C}, \mathrm{D}, \mathrm{Ca}$, zat besi, seng dan Magnesium). Berdasarkan pada pendapat ini dapat diartikan dalam kontek yang dikatakan oleh papadopoulo terjadi latihan yang terlalu berat terhadap atlet jika dilihat dari sisi penuhan gizi. Ada beberapa analisa yang dapat di ajukan. Pertama atlet makan sudak banyak dalam kuantitas tetapi rendah dalam kualitas. Kedua atlet makan hanya 3x dalam sehari, yang secara teoritis seharusnya makan sampai lima kali dengan memperhitungkan pemenuhan energy optimal untuk superkompensasi. Ketiga atlet kurang istirahat sehingga atlet memerlukan asupan nutrisi yang lebih. Keempat tidak diberikanya suplemen serta menu yang tidak bervariasi. Berangkat dari analisis diatas maka analis akan dimulai dari pemenuhan karbohidrat, lemak dan kemudian protein.

Pemenuhan karbohidrat

Secara keseluruhan pemenuhan terhadap karbihidrat sudah cukup da nada kecenderungan berlebih, dengan angka persentase kecukupan di atas 61\%. Ketika dilakukan penelitian telah memasihi perode competisi bagian taper. Pada bagian ini ketika atlet terlalu banyak mengkonsunsi karbohidat khususnya untuk kecabangan yang memerlukan pengaturan berat badan dengan angka diatas $60 \%$ bahkan ada yang mencapai $70 \%$ akan mengalami kendala dalam berat badan. Ketika program latihan tidak membakar karbohidat dengan tepat maka akan terjadi penumpukan simpanan karbohidar dalam bentuk lemak. Hal ini dapat diatasi dengan menambah pemanasan dengan jogging yang lebih atau memberikan jogging di akhir sesi latihan. Sebagai pengontrol harus disediakan timbangan sebelum dan setelah latihan. Atlet harus melakukan timbangan berat badan bangun pagi, sebelum latihan dan setelah latihan. Pengontrolan ini akan memberikan kontrol yang positif bagi atlet agar tidak terbebani dengan berat badan ketika sesi peimbangan.

\section{Penemuhan protein}

Berdasarkan tabel 2 pemenuhan protein adalah < 30\% dari kalori yang masuk. Berdasarkan tabel 3 ternyata atlet tarung drajat lebih banyak asupan protein dan justru berlebih. $100 \%$ atlet kelebihan protein. Kelebihan protein ini akan memberikan dampak pada metabolisme pada pencernaan yang memerlukan lebih dari 6 jam untuk dapat dicerna dan memerlukan oksigen yang lebih banyak jika dibandingkan dengan karbohidrat. Hal berikutnya efek dari oksidasi protein dalam proses system energy akan menghasilkan asam keto yang banyak, dalam hal ini akan merugikan atlet. Dilihat dari proses pencernaan memerlukan waktu yang lama, dilihat dari proses oksidasi memerlukan oksigen yang lebih banyak. Pemenuhan oksigen ini akan memberikan efek cepat lelah kepada atlet ketika $\mathrm{Hb}$ dalam darah tidak tinggi. Ketika oksidasi dilaksanakan maka sampah yang ditimbulkan dari oksidasi protein juga akan lebih banyak. Kajian lain adalah jika tubuh terlalu banyak asupan protein maka kelebihan dari protein ini tidak dapat disimpan, dan hanya dibuang. Proses pembuangan ini juga memerlukan energy, hal ini adalah kerugian berikutnya. Jika di lihat secara subyektif protein rasanya adalah gurih dan enak. Hal ini lah yang tidak dapat dielakkan. Ketika atlet telah 
Jurnal Ilmu Olahraga Volume I Nomor 1 Oktober 2018

Isti Dwi Puspita Wati

Tersedia di http://jurnal.untan.ac.id/index.php/jilo

menjalan latihan berat maka, keinginan untuk makan akan meningkat dan semakin meningkat ketika menu protein sebagai penyedap meningkatkan gairah untuk makan. Sebuah pelajaran yang dapat diambil adalah atlet makan bukan untuk kepuasan, tetapi lebih pada pemenuhan diet untuk mencapai prestasi yang maksimal dengan sesedikit mungkin membebani fisiologis internal. Permasalahanya adalah ketika protein terlalu banyak yang masuk dengan pencernaan yang lama dan oksidasi yang lama akan mengakibatkan kelelahan tersendiri pada fisiologi atlet.

Asupan lemak

Berdasarkan tabel 2 persentase kecukupan lemak adalah $12 \%$ dari diet asupan keseluruhan. Berdasarkan tabel 3 pemenuhan lemak atlet tarung drajat adalah $68 \%$. Asupan lemak yang cukup tinggi sampai 5 kali lipat kebutuhan. Jika dianalisis dari sisi pencernaan lemak memelukan waktu pencernaan minimal 6 jam. Dalam proses okdisasi memerlukan dua kali lipat oksigen dibandingkan dengan karbohidrat dan lebih kecil dibangingkan dengan kebutuhan oksigen terhadap okdisadi protein. Hal negative dari asupan lemak yang berlebih ini adalah pembebanan terhadap pencernaan. Hal kedua secara otomatis seperti halnya karbohidrat, ketika terjadi kelebihan maka akan disimpam dalam bentuk lemak dibawah kulit sebagai cadangan energy. Penumpulan simpanan secara terus menerus akan meningkatkan berat badan. Agar tidak terjadi peningkatan maka atlet harus melakukan latihan ekstra untuk membakar lemak yang telah terjadi. Sehingga waktu untuk pemanasan lebih panjang, waktu untuk pendinginan lebih panjang serta boros dalam penggunaan oksigen. Pembakaran lemak menghasilkan keringat yang lebih banyak dan ini akan berakibat pada hidrasi tubuh. Secara fisiologi ketika tubuh terjadi dehidrasi maka harus segera dilakukan penggantian, maka disarankan atlet harus selalu membawa air minum yang mengandung mineral agar air yang keluar lewat urine bersama dengan keringat selama latihan yang membawa mineral segara tergantikan oleh minum.

\section{KESIMPULAN}

Secara umum atlet tarung drajat mengalami kelebihan asupan gizi makro dalam persiapan keberangkatan PON. Kelebihan terutama pada lemak dan protein.

\section{DAFTAR PUSTAKA}

American College of Sport Medicine (ACSM). 2009. Nutrition and athletic performance. Med Sci Sport Exer, 41 (3) : 709-31.

American Dietetic Association (ADA). 2000. Position of the America dietetic association, deitetians of Canada, and the American College of sport medicine: Nutrition and athletic performance. J Am Diet Assoc, 100(12): 1543-1556.

Irianto, J.P. 2007. Panduan Gizi Lengkap Bagi Olahragawan. Yogykarta:

Papadopoulou. 2015. Impact of energy intake and balance on the athletic performance and health of top female volleyball athletes. Journal of the Romanian Sports Medicine Society. Medicina Sportiva (2015), vol. XI, no 1, 2477-2481.

Sherman and Kramer. 1989. Iron nutrition and exercise. In nutrition in exercise and sport. J.E. Hickson and I Wolinsky (Eds). Boca Raton, RL: CRC Press.

A. Thompson. 1998. Balance energy in young athletes. International Journal of Sport Nutrition, 1998, 8 : 160-17. 